\title{
Kajian Perilaku dan Interior Restoran Cepat Saji di Pusat Perbelanjaan
}

\author{
Vippy Dharmawan ${ }^{1}$, Fibria Conytin ${ }^{2}$, Nanik Rachmaniyah ${ }^{3}$ \\ 1,2Jurusan Teknik Arsitektur, Fakultas Teknik, Universitas Muhammadiyah Surabaya \\ Jl. Sutorejo Nomor 59 Surabaya 60113 Telp 031.3811966 \\ ${ }^{3}$ Departemen Interior, Fakultas Arsitektur, Desain, dan Perencanaan, ITS Surabaya \\ Jl. Raya Keputih, Sukolilo - Surabaya 60119 Telp 031.5925223 \\ ${ }^{1}$ masvippy@gmail.com, ${ }^{3}$ rachmaniyah@gmail.com
}

\begin{abstract}
ABSTRAK
Hubungan antara manusia dan lingkungan di ruang publik cenderung bersifat environmental determinant. Suatu hubungan dimana faktor lingkungan lebih berpengaruh dalam pembentukan perilaku manusia daripada faktor-faktor internal di dalam dirinya. Hubungan seperti itu juga berlaku di ruang publik seperti restoran cepat saji yang sekarang banyak dijumpai dalam kehidupan sehari-hari. Penelitian-penelitian sebelumnya menunjukkan bahwa di ruang publik restoran, perilaku pengunjung cenderung dipengaruhi oleh tata letak meja, view, dan privasi. Namun belum diketahui apakah perilaku serupa juga terlihat pada restoran cepat saji. Kajian ini mendeskripsikan pola-pola perilaku pengunjung dan elemen-elemen interior yang mempengaruhi perilaku tersebut pada sebuah restoran cepat saji McDonald yang terletak di sebuah pusat perbelanjaan di Surabaya. Metode yang digunakan adalah metode deskriptif analitis kualitatif yang berbasiskan pendekatan perilaku. Hasil penelitian menunjukkan bahwa aspek interior yang dominan dalam membentuk perilaku pengunjung adalah pola penataan perabot dan dinding kaca yang hampir meliputi seluruh ruang makan restoran. Adapun aspek lain yang juga mempengaruhi perilaku adalah density atau kepadatan pengunjung.
\end{abstract}

Kata kunci: interior; perilaku; restoran cepat saji

\section{ABSTRACT}

The relationship between humans and environment in public space tends to be environmental determinant. A relation in which environmental factor has more impact on human behaviour than internal factor within the human itself. This kind of relationship is also applied on public spaces such as fast food restaurant which nowadays we encounter daily. Previous research has shown that in public spaces such as restaurants, visitor's behaviour tends to be influenced by table arrangement, view, and privacy. However, it is yet unknown whether such behaviour can also be seen in fast food restaurant. This research describes visitor's behavioral pattern and interior elements that affect such behaviour in McDonald, a fast food restaurant located inside a shopping mall in Surabaya. The method used in this research is descriptive analytical qualitative method which based on behavioral approach. The result shows that interior aspect that is dominant in shaping visitor behaviour are furniture arrangement and glass wall that covered almost all dining area. Another aspect that also determine behaviour is visitor density.

Keywords: behaviour; fastfood resraurant; interior

\section{PENDAHULUAN}

Restoran cepat saji atau fastfood restaurant adalah rumah makan yang menghidangkan makanan dan minuman kepada pelanggan dalam waktu yang relatif singkat, mulai dari proses memasak hingga menghidangkannya ke pelanggan. Oleh karena mengutamakan kecepatan dalam layanannya, kebanyakan hidangan yang disajikan adalah berupa hidangan sederhana yang proses pengolahannya tidak memerlukan waktu lama. Karakteristik khas restoran jenis ini yang mengutamakan kecepatan layanan juga berpengaruh desain interiornya. Misalnya pada desain kursi meja pengunjung, kebanyakan restoran ini menggunakan meja kursi yang tidak memungkinkan pengunjung duduk berlama-lama dengan nyaman. 
Seperti halnya ruang-ruang publik lainnya, suasana yang terbentuk dalam restoran cepat saji merupakan hasil interaksi antara elemen-elemen fisik interior, kegiatan pengunjung di dalamnya, serta interaksi sosial yang menyertainya. Hubungan antara faktor-faktor tersebut bersifat timbal balik, satu dan lainnya saling mempengaruhi. Perilaku pengunjung dipengaruhi oleh suasana ruang dan mempengaruhi suasana ruang itu. Dalam hal ini perilaku merupakan bagian dari proses interaksi antara kepribadian manusia dengan lingkungan. Rangsangrangsang (stimuli) yang timbul dari lingkungan direspon oleh manusia dalam wujud perilaku. Hubungan timbal balik tersebut juga dipengaruhi oleh desain interior dan karakteristik dominan dari manusia yang berinteraksi di dalamnya. Adapun kualitas lingkungan terbentuk karena suasana ruang dipersepsi oleh pengunjung yang tercermin pada perilakunya. Sebaliknya kegiatan atau perilaku manusia itu sendiri juga mempengaruhi suasana ruang. (Gambar 1)

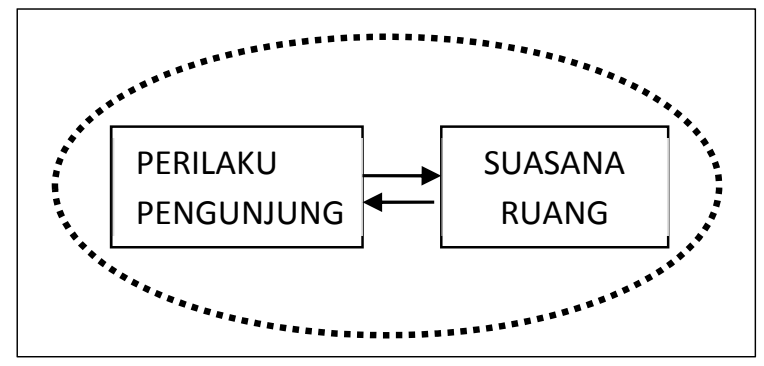

Gambar 1. Hubungan Timbal Balik antara Suasana Ruang dan Pola Perilaku Sumber: Dokumentasi Penulis (2017)

Menurut Hijaz (2007) perilaku manusia di ruang publik seperti halnya pengunjung restoran secara langsung maupun tidak langsung berkait dengan unsur-unsur 'sosiologis', 'psikologis' serta 'psikologi lingkungan'. Dengan demikian untuk membahas relasi timbal balik antara ruang publik di mall dan perilaku pengunjung adalah dengan melihatnya dalam keadaan saling terkait tidak berdiri sendiri, dalam arti bukanlah bagaimana indra pendengaran menangkap gelombang suara dari luar misalnya, ataupun bagaimana mengukur konsentrasi seseorang, melainkan membahas dengan pendekatan holistik bagaimana hubungan antara kualitas ruang yang ditampilkan oleh desain interior dan perilaku dengan kecenderungan yang ada di dalamnya.

Sementara itu studi yang dilakukan oleh Rachmaniyah (2011) menunjukkan bahwa di ruang publik pusat perbelanjaan pola perilaku individu cenderung mengikuti aturan-aturan atau norma yang berlaku di ruang publik tersebut. Dalam kajian perilaku fenomena ini sejalan dengan paham environmental determinant yang berkeyakinan bahwa perilaku manusia sangat dipengaruhi oleh lingkungannya. Paham ini melihat faktor lingkungan sebagai penentu yang dominan, dengan sedikit atau tanpa pengaruh faktor manusia sebagai pelakunya. Dengan demikian menurut paham ini, lingkungan yang sama cenderung akan menghasilkan pola perilaku yang sama atau hampir sama.

Penelitian Rachmaniyah tersebut memperkuat hasil penelitian Proshanky, Rivlin, Ittelson (1976) dan Clolok (1981) dalam Lang (1987) yang menyatakan bahwa di dalam pembentukan perilaku manusia, faktor lingkungan berperan lebih besar daripada faktor manusianya. Fenomena ini dapat dijumpai di berbagai peristiwa dan tempat-tempat publik seperti taman, mall, kantor, sekolah, stasiun, bandar udara, restoran, dan berbagai area publik lainnya. Para pengelola ruang publik berupaya mengatur atau membentuk perilaku pengunjung dengan cara menata desain ruang-ruang publik tersebut.

Dalam kehidupan sehari-hari, hal serupa dilakukan oleh para pengelola restoran cepat saji. Berbagai restoran cepat saji menjual suasana ruang yang berbeda-beda untuk menarik 


\section{Di|Fink}

Vol. 3, No. 2, Desember 2018, pISSN 2527-2853, eISSN 2549-2985

pelanggan berkunjung. Lazimnya restoran cepat saji waralaba seperti McDonald, KFC, atau merk lokal seperti Ayam D'Besto, menggunakan elemen-elemen interior tertentu sebagai ciri khasnya seperti pilihan warna, desain logo, desain perabot, dan sebagainya. Ciri khas ini menjadikan restoran tersebut mudah dikenal oleh pengunjung. Suasana yang tercipta pun juga menjadi ciri khas restoran tersebut. Namun seperti yang telah diuraikan di atas, faktor yang mempengaruhi suasana restoran cepat saji tidak hanya faktor desain interior. Faktor lainnya seperti perilaku pengunjung dan interaksi sosial juga berpengaruh. Pada restoran yang sama misalnya, suasana di waktu pengunjung padat dan waktu pengunjung sepi pasti berbeda. Demikian juga saat ada event khusus seperti acara ulang tahun atau promosi produk suasana yang tercipta akan berbeda.

Apa yang dikemukakan oleh Rachmaniyah diperkuat dengan hasil penelitian Wida dan kawan-kawan (2017). Penelitian yang dilakukan pada beberapa kafe di kota Bandung tersebut bertujuan untuk mengetahui faktor-faktor yang mempengaruhi kenyamanan duduk pengunjung di kafe. Hasil penelitian menunjukkan bahwa perilaku kenyamanan pengunjung lebih didominasi oleh faktor-faktor eksternal, seperti letak tempat duduk, view atau pemandangan, dan privasi.

Dengan demikian perlu dikaji elemen-elemen interior apa saja yang mempengaruhi perilaku pengunjung di restoran cepat saji. Selain itu juga perlu diketahui pola-pola perilaku pengunjung restoran yang terbentuk ketika berada di dalam restoran. Kemudian dari interaksi antara kedua aspek pembentuk setting perilaku tersebut, dapat diketahui suasana apakah yang akan terbentuk.

\section{METODE PENELITIAN}

Metode yang digunakan untuk mengetahui bagaimana interaksi antara pengunjung dan lingkungan fisik di restoran ini adalah deskriptif analitis dengan menggunakan teknik observasi dan pemetaan perilaku. Observasi dilakukan terhadap elemen-elemen fisik interior serta sikap dan perilaku pengunjung pada tempat dan waktu yang telah ditentukan terlebih dahulu. Sedangkan pemetaan perilaku pengunjung dilakukan untuk mengetahui pergerakan pengunjung di dalam restoran. Cara yang digunakan ada dua, yaitu dengan teknik person centered mapping dan place centered mapping. Cara yang pertama menekankan pada pergerakan pengunjung yang diamati, sedangkan cara yang kedua lebih menekankan pada bagaimana pengunjung memanfaatkan dan mengakomodasi perilakunya pada tempat dan waktu-waktu tertentu.

Penggunaan teknik person centered mapping diawali dengan observasi awal terhadap pergerakan pengunjung restoran. Selanjutnya pengamat mengidentifikasi waktu dan pola-pola pergerakan berulang yang dilakukan oleh pengunjung, kemudian mengkategorikannya. Sedangkan teknik place centered mapping dilakukan dengan terlebih dahulu membuat peta atau denah restoran dan menandai area-area yang perlu diamati dengan seksama. Setelah itu pengamat mencatat bagaimana pengunjung berperilaku pada area-area yang telah ditandai.

\section{HASIL PENELITIAN DAN PEMBAHASAN}

\section{A. Restoran McDonald Plasa Surabaya}

Sebagai bahan kajian adalah sebuah restoran cepat saji McDonald yang terletak di Plasa Surabaya, salah satu pusat perbelanjaan yang tertua dan terbesar di Surabaya. Restoran McDonald adalah salah satu tenant utama di pusat perbelanjaan ini. McDonald sendiri memiliki setidaknya sepuluh gerai yang tersebar di berbagai pusat-pusat keramaian kota Surabaya. Geraigerai tersebut sebagian berada di gedung sendiri atau free standing, sebagian lainnya terletak di dalam area pusat perbelanjaan atau kompleks ruko. Adapun desain eksterior maupun interiornya mempunyai kemiripan satu sama lainnya, karena banyak dari elemen-elemen 
desainnya sudah menjadi ikon McDonald Restoran ini beroperasi selama dua puluh empat jam sehari dan tujuh jam seminggu, walaupun pusat perbelanjaan ini hanya buka mulai pukul sepuluh pagi hingga pukul sepuluh malam.

Area yang ditempati oleh McDonald berada di pojok timur-selatan Plasa ini dan langsung berdekatan dengan area parkir mobil. Dari dalam area restoran ke arah selatan pengunjung bisa melihat area parkir dan jalan raya. Sedangkan ke arah timur pengunjung dapat melihat jalan keluar masuk mall serta lapangan parkir timur. Akses langsung ke dalam restoran bisa dari dua buah pintu yang menghadap area parkir dan satu buah pintu yang berhubungan dengan koridor di dalam mall. Adanya tiga pintu masuk dari arah parkir dan koridor dalam ini membuat restoran tersebut terkadang menjadi tempat lewat bagi pengunjung yang keluar masuk Plasa. (Gambar 2)



Gambar 2. Lokasi Restoran McDonald di Plasa Tunjungan Surabaya Sumber: Google Map (2017)

\section{B. Setting Fisik}

Interior restoran ini mempunyai karakter khas waralaba McDonald. Suasana ini terbentuk karena terdapat elemen-elemen interior yang menjadi kekhasan perusahaan waralaba ini. Warna khas perusahaan yaitu kombinasi kuning dan merah dapat dijumpai di berbagai bagian interior, seperti: area bermain anak, berbagai poster dan banner, serta billboard di belakang outlet pelanggan. Elemen interior lain yang juga menjadi kekhasan dari restoran jni adalah warna dark brown dof pada kursi makan dan kusen, lapisan HPL bercorak dark walnut dan light walnut, bahan vinyl sofa berwarna light grey.

Layout ruangan dibagi dalam beberapa area, yaitu area dapur dan servis, area outlet, area makan utama, area makan tambahan, ruang acara, area bermain anak, dan area teras. Area outlet adalah tempat pelanggan memesan, membayar, dan mengambil hidangan. Area ini berhubungan langsung dengan area dapur dan servis. Area makan utama berbentuk memanjang dan berhubungan langsung dengan area outlet serta teras. Meja-kursi pada area makan ini jumlah dan jenisnya paling banyak bila dibanding area makan tambahan dan area teras. Adapun area makan tambahan posisinya agak jauh dari outlet. (Gambar 3.) 


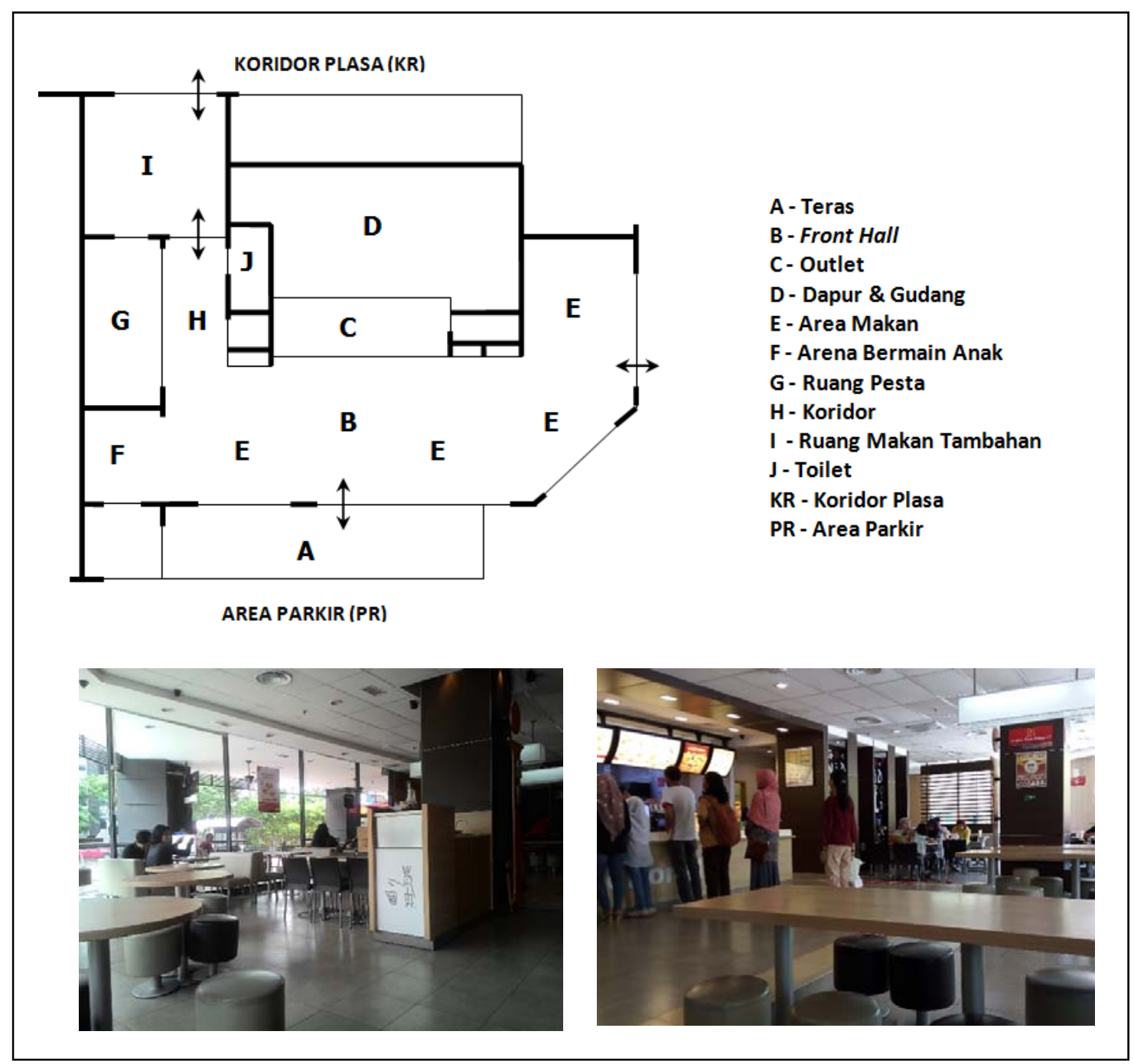

Gambar 3. Setting Fisik Restoran McDonald di Plasa Tunjungan Surabaya Sumber: Dokumentasi Penulis (2017)

\section{Pola Pergerakan Pengunjung}

Perilaku pengunjung restoran menunjukkan pola-pola pergerakan tertentu yang selalu berulang. Observasi dengan teknik person centered mapping mendapatkan bermacam-macam pola urutan aktivitas pengunjung seperti terlihat pada tabel 1 berikut. Pengamatan dilakukan pada saat pengunjung ramai, sedang, dan sepi. Adanya tiga akses masuk ke restoran serta ruang tempat makan yang terpencar-pencar mengakibatkan terjadinya pola-pola pergerakan pengunjung yang cenderung beragam dan tidak linier. Hal ini menimbulkan suasana yang gaduh pada saat restoran ramai pengunjung, namun juga memberi kesan bebas dan tidak formal sesuai konsep layanan restoran McDonald. 
Vippy Dharmawan, Fibria Conytin, Nanik Rachmaniyah

Kajian Perilaku dan Interior Restoran Cepat Saji di Pusat Perbelanjaan

Tabel 1. Daftar Pola Pergerakan Pengunjung

\begin{tabular}{|c|c|c|}
\hline Tipe & $\begin{array}{c}\text { Urutan } \\
\text { Aktivitas }\end{array}$ & Suasana Restoran \\
\hline$(1)$ & PR-A-B-C-E-A-PR & ramai, sedang, sepi \\
\hline$(2)$ & PR-A-B-C-E-F-E-A-PR & ramai, sedang, sepi \\
\hline$(3)$ & PR-A-F-C-E-A-PR & ramai, sedang, sepi \\
\hline$(4)$ & PR-A-E-A-PR & ramai \\
\hline$(5)$ & PR-A-B-H-I-KR & ramai \\
\hline$(6)$ & PR-A-B-C-E-H-I-KR & ramai, sedang, sepi \\
\hline$(7)$ & PR-A-B-C-E-J-E-A-PR & ramai, sedang, sepi \\
\hline$(8)$ & PR-A-B-C-B-A-PR & ramai, sedang, sepi \\
\hline$(9)$ & PR-E-C-E-PR & ramai, sedang, sepi \\
\hline$(10)$ & PR-E-F-C-E-PR & ramai, sedang, sepi \\
\hline$(11)$ & PR-E-F-C-E-H-I-KR & ramai, sedang, sepi \\
\hline$(12)$ & PR-E-PR & ramai \\
\hline$(13)$ & PR-E-H-I-KR & ramai \\
\hline$(14)$ & PR-E-C-E-H-I-KR & ramai, sedang, sepi \\
\hline$(15)$ & PR-E-C-E-J-E-PR & ramai, sedang, sepi \\
\hline$(16)$ & PR-E-C-B-A-E-PR & ramai, sedang, sepi \\
\hline$(17)$ & KR-I-H-C-E-H-I-KR & ramai, sedang, sepi \\
\hline$(18)$ & KR-I-H-F-C-E-H-I-KR & ramai, sedang, sepi \\
\hline$(19)$ & KR-I-H-F-C-E-PR & ramai, sedang, sepi \\
\hline$(20)$ & KR-I-KR & ramai \\
\hline$(21)$ & KR-I-H-B-E-PR & ramai \\
\hline$(22)$ & KR-I-H-B-A-PR & ramai \\
\hline$(23)$ & KR-I-H-C-E-PR & ramai, sedang, sepi \\
\hline$(24)$ & KR-I-H-C-E-J-H-KR & ramai, sedang, sepi \\
\hline$(25)$ & KR-I-H-C-B-A-B-H-I-KR & ramai, sedang, sepi \\
\hline & & \\
\hline
\end{tabular}

Riuh dan gaduhnya suasana ketika restoran sedang ramai antara lain disebabkan banyaknya pengunjung yang hanya sekedar melintas ruangan. Baik pengunjung yang melintas masuk dari arah koridor plasa, melewati ruang makan, lalu keluar menuju tempat parkir dari pintu lainnya, maupun pengunjung yang melintas dari arah sebaliknya.

Hasil pengamatan juga menunjukkan bahwa selain menikmati hidangan, pengunjung juga datang untuk mengasuh anaknya di arena bermain, serta sekedar melintas dari dalam lalu ke luar Plasa dan sebaliknya. Juga didapati pengunjung yang sekedar duduk-duduk di dalam area restoran tanpa membeli hidangan. Kedua perilaku yang terakhir tersebut cenderung dilakukan ketika restoran sedang ramai oleh pengunjung. Suasana yang ramai membuat pengunjung sibuk dengan aktivitasnya sendiri-sendiri, sehingga pengunjung yang tidak membeli hidangan tidak merasa rikuh karena tidak menarik perhatian pengunjung yang lain.

Selain itu saat diamati lebih dalam, ditemukan bahwa kepadatan restoran juga berpengaruh pada lama waktu pengunjung duduk di meja makan. Pada saat restoran ramai pengunjung cenderung tidak berlama-lama duduk dimeja makan. Kondisi sebaliknya terjadi ketika restoran sedang sepi. Kondisi yang gaduh dan ramai nampak mempengaruhi kenyamanan pengunjung dalam menikmati hidangan.

\section{Perilaku Saat Menggunakan Ruang}

Hasil dan pengamatan dengan teknik placed centered mapping mendapatkan bermacammacam perilaku pengunjung. Perilaku pengunjung yang diamati adalah kecenderungan dalam memilih tempat duduk dan area atau ruang tempat menikmati hidangan. Perilaku-perilaku tersebut berkorelasi dengan setting fisik restoran. Disini terlihat bahwa elemen interior, penataan layout ruang, maupun suasana yang terbentuk oleh perilaku pengunjung dapat 
mempengaruhi perilaku pengunjung itu sendiri ketika berada di dalam area restoran. Selain faktor-faktor tersebut, perilaku pengunjung dalam memilih tempat bersantap juga dipengaruhi oleh waktu. Ini terlihat dari kepadatan pengunjung di tiap ruang makan berbeda-beda pada waktu yang berlainan.

Elemen interior seperti kursi makan berpengaruh pada perilaku pengunjung. Berdasarkan desain dan bahannya ada empat macam kursi yang disediakan untuk pelanggan, yaitu: kursi model sofa, kursi berbahan vinyl dengan rangka besi, bangku sofa bulat dan kursi besi model outdoor (Gambar 4). Hasil pengamatan menunjukkan bahwa kebanyakan pengunjung lebih memilih meja dengan kursi sofa dibanding jenis kursi lainnya. Yang menjadi kursi favorit kedua bagi pengunjung adalah kursi vinyl dan yang terakhir adalah kursi model bulat. Adapun pengunjung yang memang memilih posisi bersantap di area teras harus menikmati hidangan di meja dengan kursi model outdoor, karena hanya jenis kursi tersebut yang disediakan di area teras.

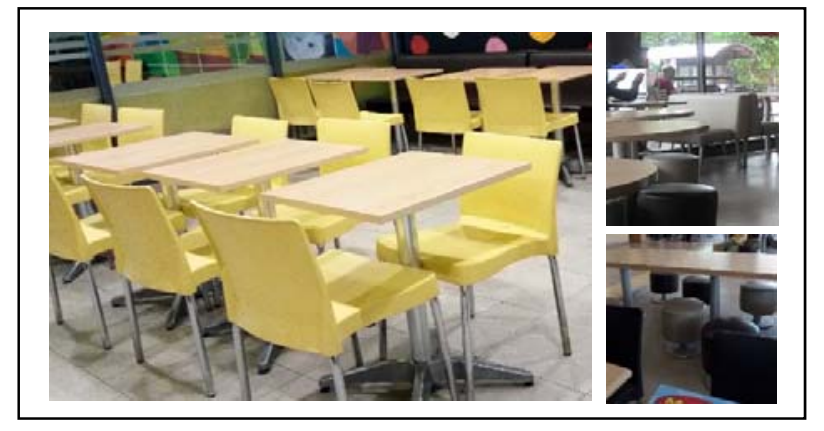

Gambar 4. Kursi Pengunjung Restoran

Sumber: Dokumentasi Penulis (2017)

Sementara itu perilaku pengunjung dalam memilih posisi duduk atau bersantap berubahubah dari waktu ke waktu. Gambar 5 dan Gambar 6 menunjukkan bahwa pada pagi hari ketika Plasa belum buka dan restoran masih sepi, pengunjung cenderung memilih posisi duduk dekat dinding kaca yang menghadap ke arah Jalan Pemuda atau di teras. Pada saat itu area makan yang berhubungan langsung dengan ruang dalam Plasa tidak terisi sama sekali oleh pengunjung karena Plasa masih belum buka.

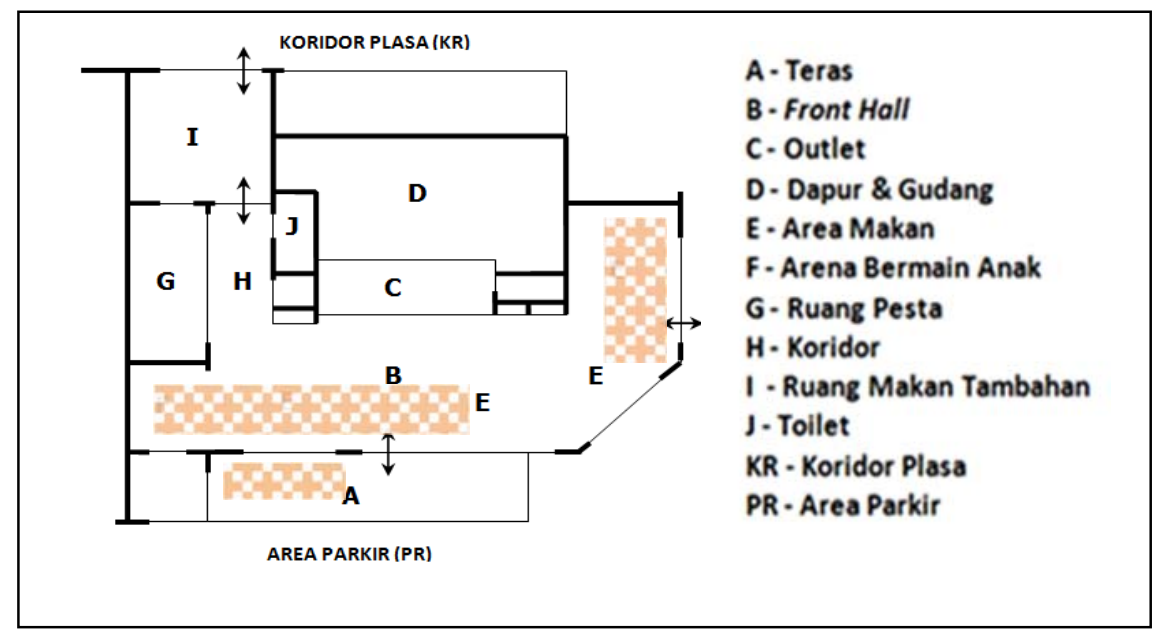

Gambar 5. Posisi yang Cenderung Dipilih Pengunjung Saat Pagi Hari Sumber: Dokumentasi Penulis (2017) 


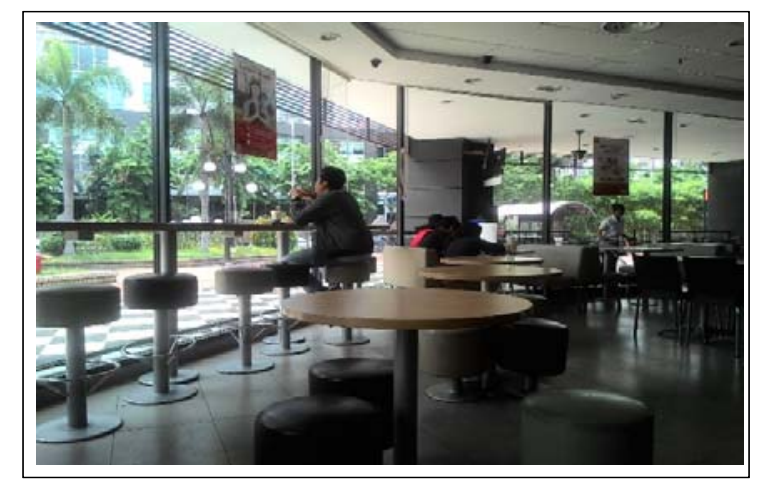

Gambar 6. Pengunjung Memilih Posisi Duduk Dekat Dinding Kaca Dengan View ke Jalan Pemuda Sumber: Dokumentasi Penulis (2017)

Selanjutnya pada saat Plasa mulai buka hingga waktu makan siang, kecenderungan posisi duduk pengunjung mengalami perubahan. Pengunjung tersebar merata di ruang makan utama, teras, dan ruang makan tambahan. Namun kepadatan pengunjung paling tinggi berada di ruang makan utama yang mempunyai akses langsung ke konter layanan. Pada jam-jam makan siang atau sekitar pukul 11.30 hingga pukul 13.00 kepadatan pengunjung tinggi dan merata di ruang makan utama dan ruang makan tambahan. Sebaliknya di teras pengunjung yang duduk di situ mulai berkurang karena suasana mulai terasa panas dan silau. (Gambar 7.)



Gambar 7. Posisi yang Cenderung Dipilih Pengunjung Saat Siang Hari Sumber: Dokumentasi Penulis (2017)

Menjelang sore hari kepadatan pengunjung mulai berkurang. Posisinya tersebar merata di ruang makan utama, teras, dan ruang makan tambahan. Pada masing-masing ruang kursi pengunjung terisi dengan kisaran setengah hingga tiga perempatnya (Gambar 8.). Pada situasi seperti ini terlihat bahwa kecenderungan posisi duduk pengunjung yang merata di tiga area tersebut menunjukkan bahwa elemen-elemen lingkungan berpengaruh pada pilihan posisi duduk. Pengunjung yang lebih berkepentingan dengan aktivitas di Plasa memilih duduk di area makan tambahan yang mempunyai akses langsung ke Plasa. Demikian juga yang berada di area teras memilih duduk disitu karena berkepentingan dengan view langsung ke jalan dan suasana 
semi outdoor di teras. Adapun yang memilih duduk di area makan utama merasa lebih nyaman duduk dekat konter layanan yang menjadi pusat orientasi area ini.

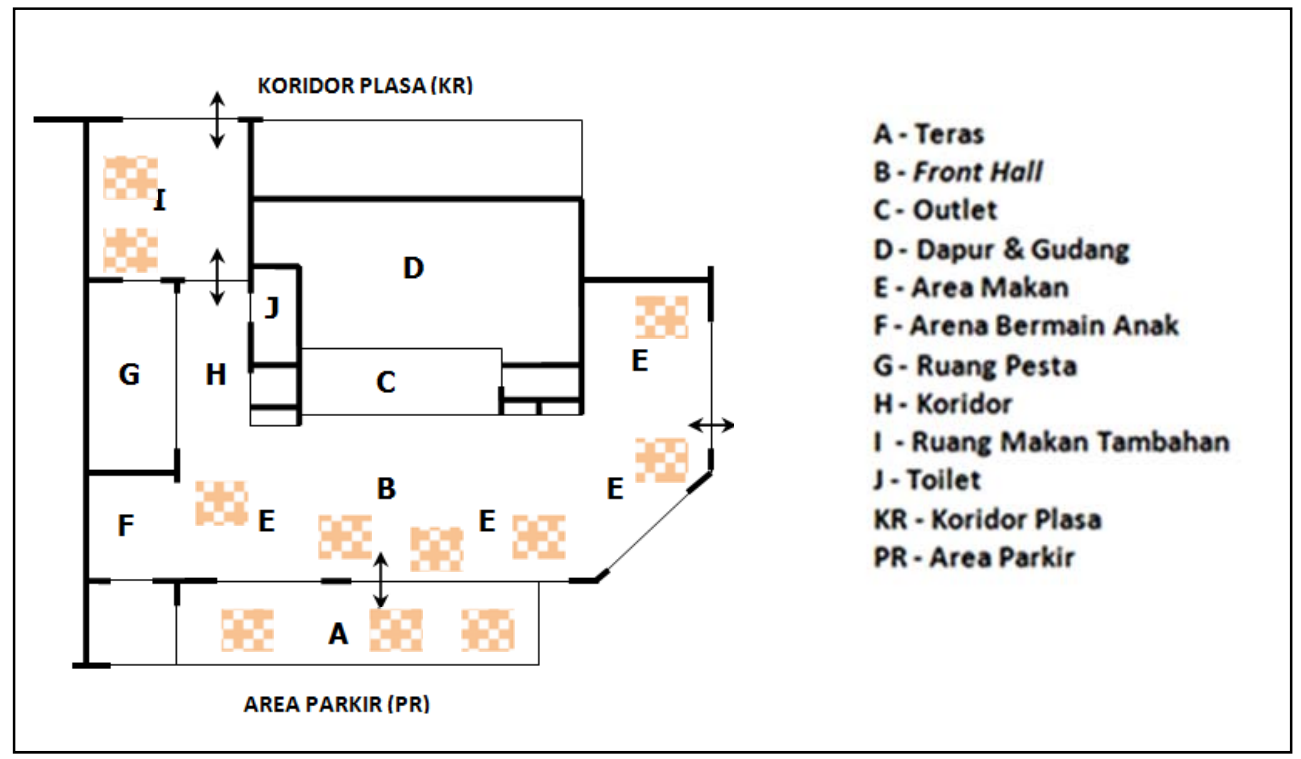

Gambar 8. Posisi yang Cenderung Dipilih Pengunjung Saat Sore Hari Sumber: Dokumentasi Penulis (2017)

Selanjutnya pada saat malam hari, pukul 18.00 hingga 20.30, kepadatan pengunjung kembali bertambah. Posisi pengunjung masih tersebar merata di ruang makan utama, teras, dan ruang makan tambahan. Kursi pengunjung cenderung terisi penuh (Gambar 9.) Suasana keramaian hampir menyerupai saat siang hari, namun bedanya adalah kursi pengunjung di area teras juga terisi hampir penuh. Hal yang menarik adalah bahwa posisi duduk di ruang dalam yang sejuk tidak lebih disukai dibandingkan posisi duduk di teras.

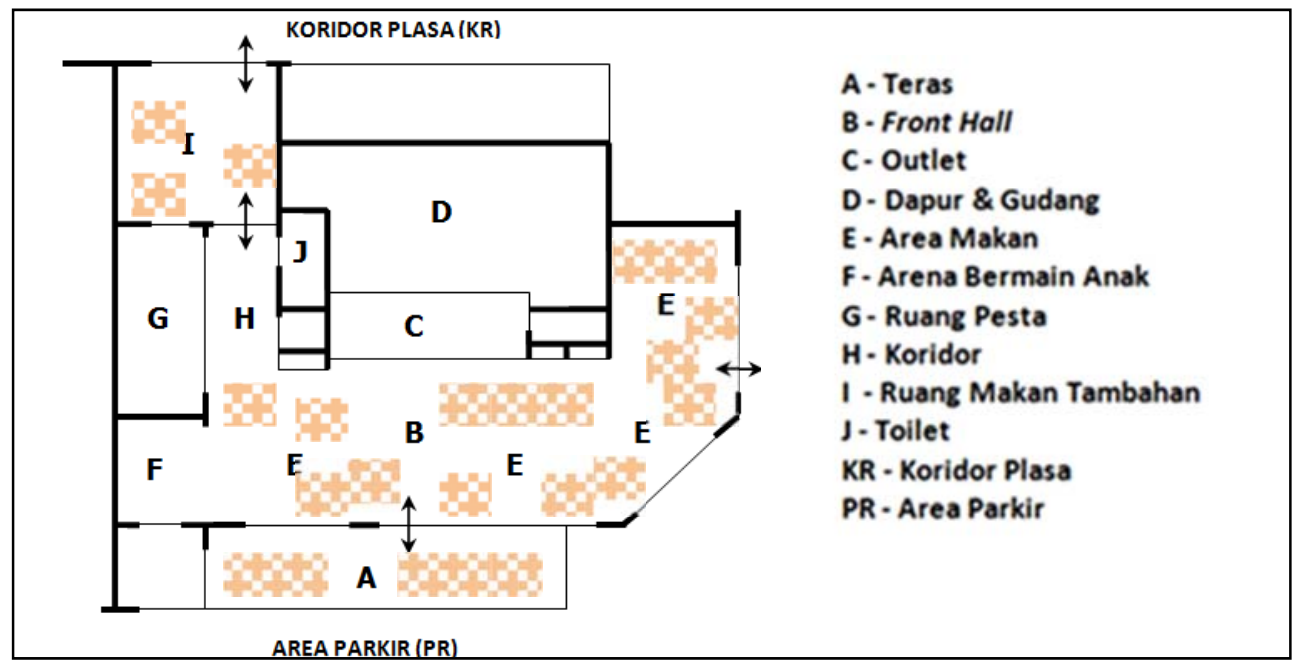

Gambar 9. Posisi yang Cenderung Dipilih Pengunjung Saat Malam Hari Sumber: Dokumentasi Penulis (2017) 
Saat Plasa mulai tutup, akses dari Plasa ditutup juga. Pengunjung mulai berkurang sedikit demi sedikit hingga menjelang dini hari. Konsentrasi pengunjung ada pada ruang makan utama dan area teras (Gambar 10). Disini terlihat ada pengaruh dominan akses dari Plasa terhadap keramaian di ruang makan tambahan. Pintu dari arah plasa menjadi stimulus utama bagi pengunjung. Begitu akses ditutup maka ruang makan tambahan tersebut akan menjadi pilihan akhir bagi pengunjung untuk memilih posisi duduk di situ. Sebaliknya ruang makan utama dan teras tetap menjadi pilihan pengunjung karena ada stimulus berupa outlet layanan dan suasana semi outdoor yang ditawarkan oleh area teras.

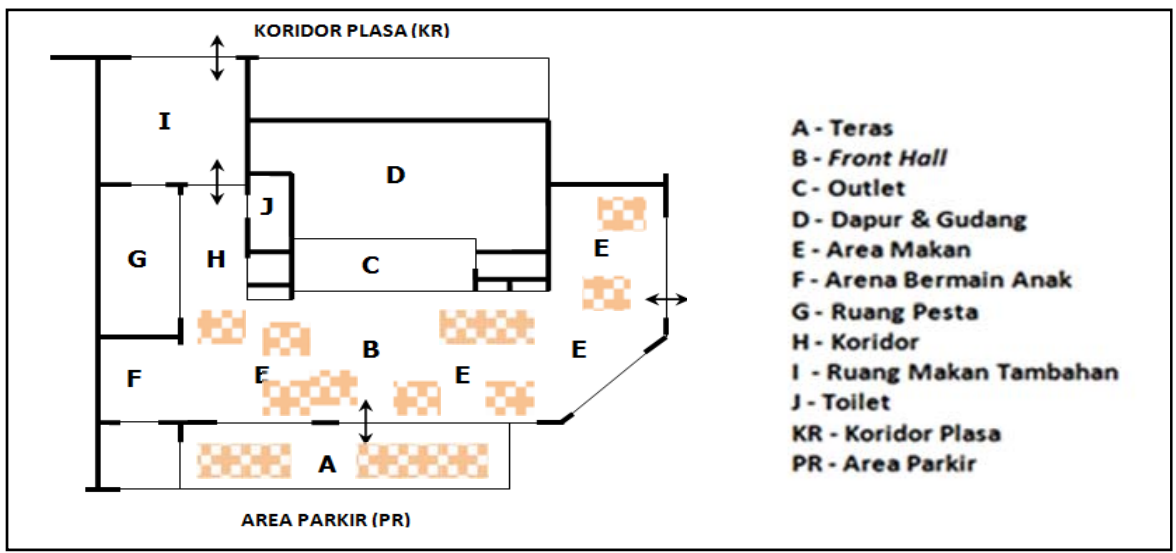

Gambar 10. Posisi yang Cenderung Dipilih Pengunjung Saat Plasa Sudah Tutup Sumber: Dokumentasi Penulis (2017)

\section{KESIMPULAN}

Dari uraian di atas dapat disimpulkan bahwa aspek interior yang dominan dalam membentuk perilaku pengunjung adalah jenis dan penempatan perabot serta elemen pembentuk dinding. Adapun aspek lain yang juga mempengaruhi perilaku adalah density atau kepadatan pengunjung yang berbeda-beda tergantung waktu berkunjung.

Hasil tersebut di atas sejalan dengan penelitian-penelitian sebelumnya yang menunjukkan bahwa di ruang publik seperti restoran interaksi antara manusia dan lingkungannya lebih cenderung bersifat environmental determinant. Dalam hal ini terlihat bahwa lingkungan yang sama atau sejenis cenderung akan menghasilkan pola perilaku yang sama atau hampir sama.

\section{DAFTAR PUSTAKA}

Haryadi dan Setiawan B. (1995). Arsitektur Lingkungan dan Perilaku. Jakarta: DITJEN DIKTI Departemen Pendidikan dan Kebudayaan.

Hijaz, Taufan. (2007). Desain Interior dan Perilaku Pengunjung di Ruang Publik, Studi Kasus Kelapa Gading Mall Jakarta. Jurnal Dimensi Interior. Vol. \% No. 2 Edisi Desember. Bandung: ITB.

Lang, Jon. (1987). Creating Architectural Theory. New York: Van Nostrand Reinhold Company.

Rachmaniyah, Nanik. (2011). Teori Perilaku dan Ruang Publik. Jurnal Desain IDEA. Vol. 14 No.1 Edisi Februari. Surabaya: ITS.

Wida, Alifia Izzati Dkk. (2017). Teori Relasi Desain dan Tata Letak Sarana Duduk Terhadap Kenyamanan Pengunjung Kafe. Jurnal Desain Interior Vol. 2 No.1 Edisi Februari. Surabaya: ITS. 